\title{
Prediction of COVID-19 mortality among hospitalized patients in Sudan
}

1. Ghada Omer Hamad Abd El-Raheem*, Pharmacy Department, American Board Certified Critical Care Clinical Pharmacist, Imperial Specialized Hospital, Alsharif Alhindi street, Khartoum, Sudan. Tel: +249 183 773861. E-mail: imperialhospital@ outlook.com City: 11114Khartoum, State: 11111-Khartoum, Country: 79371-Sudan

E-mail: ghadaomer90@gmail.com. Phone numbers: +249922572830 / + 249902623636

2. Maysoun Ahmed Awad Yousif, Emergency department, Senior Medical Officer, Imperial Specialized Hospital, Alsharif Alhindi street, Khartoum, Sudan. Tel: +249 183 773861. E-mail: imperialhospital@ outlook.com City: 11114- Khartoum, State: 11111-Khartoum, Country: 79371-Sudan

E-mail: misakadeesa@icloud.com ,Phone number:+249913788234

3. Doaa Salih Ibrahim Mohamed, Emergency department, Senior Medical Officer, Imperial Specialized Hospital, Alsharif Alhindi street, Khartoum, Sudan. Tel: +249 183 773861. E-mail: imperialhospital@outlook.com City: 11114- Khartoum, State: 11111-Khartoum, Country: 79371-Sudan

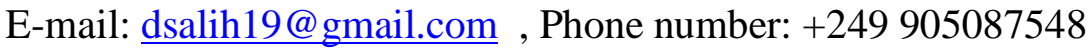

*Corresponding author: ghadaomer90@gmail.com. 
medRxiv preprint doi: https://doi.org/10.1101/2021.03.09.21253179; this version posted March 11, 2021. The copyright holder for this preprint (which was not certified by peer review) is the author/funder, who has granted medRxiv a license to display the preprint in perpetuity.

It is made available under a CC-BY-NC-ND 4.0 International license .

\section{Abstract}

Background: COVID-19 was primarily reported in China. The mortality rate across countries had ranged from $1 \%$ up to more than $10 \%$ and it is underestimated in some countries. Advanced age is the most frequently reported factor associated to mortality. Other factors were the presence of comorbidities such as diabetes mellitus, hypertension and obesity. Several models for mortality prediction had been developed to assist in improving the prognosis. The aim of our study was to assess the factors related to mortality among COVID-19 patients and develop a prediction model based on these factors.

Methods: A retrospective cohort study assessed the factors related to the mortality among COVID19 patients who attended Imperial Hospital isolation centre on November- December, 2020, Khartoum, Sudan. Statistical tests performed were chi-square test, odds ratio and regression to develop the prediction model. Tests were considered statistically significant when $p<0.05$.

Results: 105 patients were studied. $29 \%$ of the patients were deceased, while, $71 \%$ were discharged alive. A statistically significant association was found between the age and severity with regards to mortality rate $(p=0.034,0.018$ respectively). The model equation for mortality prediction: Mortality $=$ $-14.724+(1.387 *$ Age $)+(-0.323 *$ Gender $)+(1.814 *$ Admission $)+(0.193 *$ Ischemic Heart Disease $)$

$+(-0.369 *$ Fever $)+\left(1.595^{*}\right.$ Cough $)+\left(1.953^{*}\right.$ Complications $)+(0.149 *$ Duration of hospitalization $)+(0.999 *$ Enoxaparin dose $)$.

Conclusions: Age, admission ward, cough and enoxaparin dose were statistically significant predictors for COVID-19 mortality ( $p=0.014,0.011,0.015,0.006$ respectively).

Keywords: COVID-19, corona virus, mortality, prediction, Imperial Hospital, Sudan, Sudanese patients. 


\section{Background}

COVID-19 infection is considered a pandemic across the whole world and has been declared as a global public health emergency situation by the world health organization $[1,2]$. COVID-19 was primarily reported in China [3]. The mortality rate across countries had ranged from $1 \%$ up to more than $10 \%$ [4] and it is underestimated in some countries [5]. Advanced age is the most frequently reported factor associated to mortality $[4,6]$. Hence focus was applied for older population [6]. Other factors were the presence of comorbidities such as diabetes mellitus (DM), hypertension (HTN) and obesity [2]. COVID-19 infection can lead to multi thrombotic events [7], coagulation abnormality was also proposed to be associated with mortality of COVID-19 patients [8]. Climate factors were associated with the mortality rates of COVID-19 infection as well, such as humidity and temperature especially in African countries [9]. As well as, severe air pollution [10]. Patients with cardiovascular co-morbid conditions were considered vulnerable as well [11]. Several models for mortality prediction had been developed to assist in improving the prognosis $[12,13]$. in the other hand, epidemiological models for forecasting the excess mortality and for forecasting the pandemic itself were developed $[14,15]$. Many mortality scores were developed to predict COVID-19 outcomes [3, 16, 17]. United nations, OCHA reported that the average COVID-19 daily cases in Sudan had reached 300 cases in December 2020, with Khartoum State accounting for $78 \%$ of the reported cases [18]. The aim of our study was to assess the factors related to mortality among COVID-19 patients and develop a prediction model based on these factors.

\section{Methods}

A retrospective cohort study was conducted to assess the factors related to the mortality among COVID-19 patients who attended Imperial Hospital- Isolation centre on November- December, 2020, Khartoum State, Sudan. Imperial Hospital is a 60 bed hospital. It contains three isolation wards. General isolation wards were 2 with 10 beds capacity each, while, the isolation ICU had 5 beds capacity. The sample of 105 files of adult COVID-19 patients was collected randomly from the hospital registry. Patients who 
attended in November 2020 and December 2020 were involved in the study. The characteristics of the patients and the mortality related risk factors were recorded. Statistical package for social sciences (SPSS version 23) was used to describe and analyse the data. Statistical analysis tests performed were chi-square tests to determine association among variables, odds ratio and regression to develop the prediction model. Tests were considered statistically significant when $p<0.05$.

\section{Results}

\section{Mortality status among patients at Imperial Hospital}

105 patients were involved in the study. $29 \%$ of the patients were deceased, while, $71 \%$ were discharged alive.

\section{Demographic characteristics of COVID-19 patients based on the mortality status}

105 patients were involved in the study. Age was assessed with regards to mortality status. None of the patients who aged $\leq 45$ years had died. While, $(21.1 \%)$ of the patients who aged between 46 and 60 years were deceased. In the other hand, the percent of the deceased patients at the age above 60 years was (33.3\%). There was a statistically significant association $(p=0.034)$ between mortality rate and the age of the patients.

Regarding gender and comorbid conditions of the patients, there was no statistically significant association between these characteristics and mortality $(p>0.05)$.

Of the patients who were admitted to general isolation wards, $23.5 \%$ were deceased. While, among the patients who were admitted to the isolation ICU, 50\% were deceased. A statistically significant association $(p=0.018)$ was found between the hospital admission and mortality. Table 1 below illustrated the association between the demographic characteristics of the patients and mortality. 
Table 1: Demographic characteristics of COVI-19 patients based on the mortality status $\underline{(n=105)}$

\begin{tabular}{lcccccccc}
\hline & \multicolumn{9}{c}{ Mortality } & & & \\
Characteristics & Deceased & $\mathbf{\%}$ & Alive & $\mathbf{\%}$ & Total & $\mathbf{\%}$ & $\mathbf{C h i}^{\mathbf{2}}$ & $\boldsymbol{p}$-value \\
\hline Age & & & & & & & $6.784^{*}$ & 0.034 \\
30- 45 Years & 0 & 0.0 & 8 & 100.0 & 8 & 7.6 & & \\
46- 60 Years & 4 & 21.1 & 15 & 78.9 & 19 & 18.1 & & \\
>60 Years & 26 & 33.3 & 52 & 66.7 & 78 & 74.3 & & \\
Total & $\mathbf{3 0}$ & $\mathbf{2 8 . 6}$ & $\mathbf{7 5}$ & $\mathbf{7 1 . 4}$ & $\mathbf{1 0 5}$ & $\mathbf{1 0 0 . 0}$ & & \\
Gender & & & & & & & 0.261 & 0.609 \\
Male & 20 & 30.3 & 46 & 69.7 & 66 & 62.9 & & \\
Female & 10 & 25.6 & 29 & 74.4 & 39 & 37.1 & & \\
Total & $\mathbf{3 0}$ & $\mathbf{2 8 . 6}$ & $\mathbf{7 5}$ & $\mathbf{7 1 . 4}$ & $\mathbf{1 0 5}$ & $\mathbf{1 0 0 . 0}$ & & \\
Comorbid conditions & & & & & & & 0.718 & 0.397 \\
Yes & 24 & 30.8 & 54 & 69.2 & 78 & 74.3 & & \\
No & 6 & 22.2 & 21 & 77.8 & 27 & 25.7 & & \\
Total & $\mathbf{3 0}$ & $\mathbf{2 8 . 6}$ & $\mathbf{7 5}$ & $\mathbf{7 1 . 4}$ & $\mathbf{1 0 5}$ & $\mathbf{1 0 0 . 0}$ & & \\
Admission & & & & & & & 5.559 & 0.018 \\
Isolation ward & 20 & 23.5 & 65 & 76.5 & 85 & 81.0 & & \\
Isolation ICU & 10 & 50.0 & 10 & 50.0 & 20 & 19.0 & & \\
Total & $\mathbf{3 0}$ & $\mathbf{2 8 . 6}$ & $\mathbf{7 5}$ & $\mathbf{7 1 . 4}$ & $\mathbf{1 0 5}$ & $\mathbf{1 0 0 . 0}$ & & \\
\hline
\end{tabular}

*Likelihood ratio

\section{Comorbid conditions of COVID-19 patients with regards to mortality}

The comorbidities of COVID-19 patients were determined, the reported comorbid conditions were diabetes mellitus (DM), hypertension (HTN), DM with HTN and ischemic heart disease (IHD). There was no statistically significant association between comorbidities and COVID-19 mortality $(\mathrm{p}=0.386,0.083,0.073,0.872$ respectively). Figure 1 below illustrates the percentage of deceased patients among each comorbid condition. 


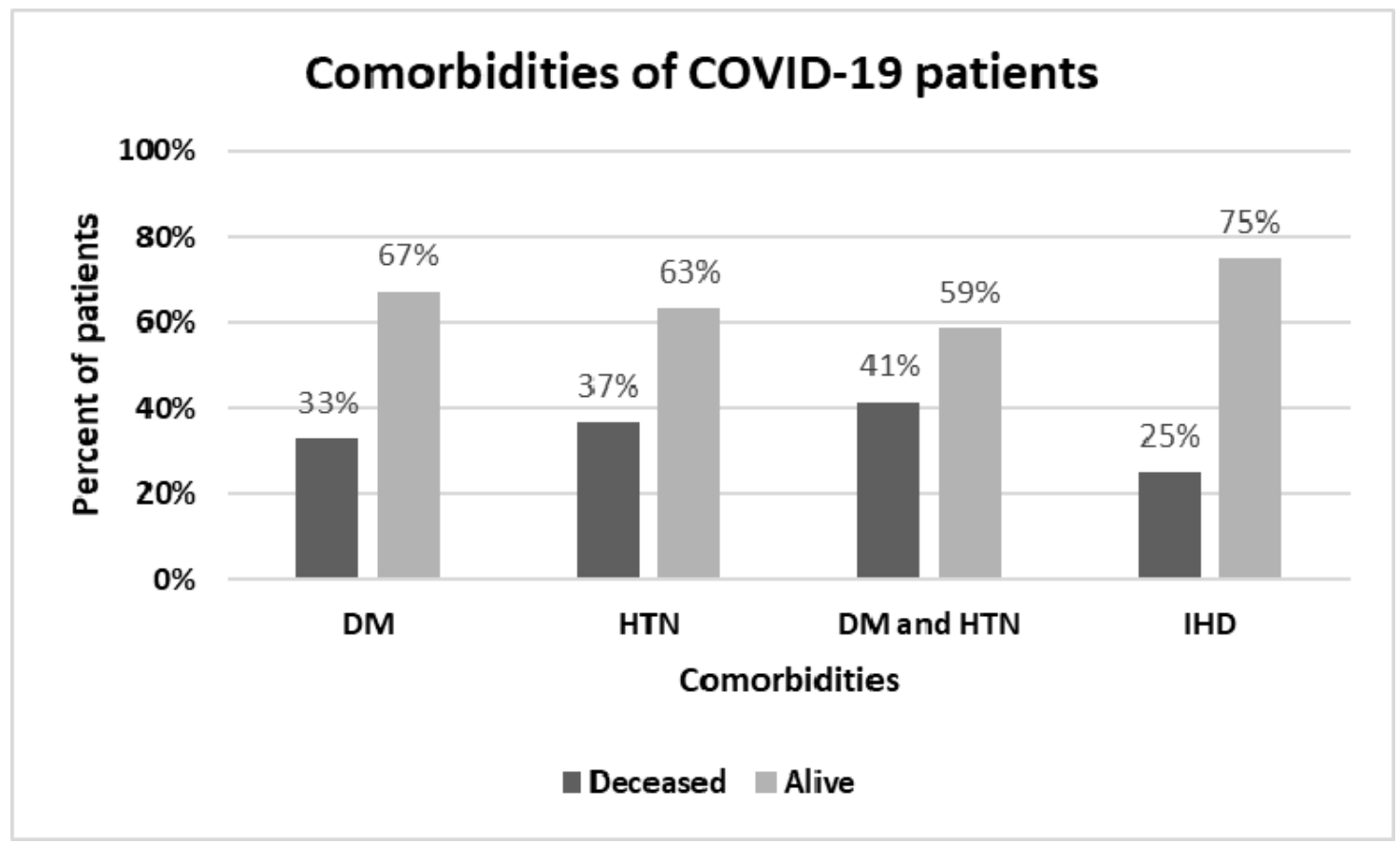

Figure 1: Comorbidities of COVID-19 patients based on the mortality status

\section{COVID-19 presentation and treatment among participants based on their mortality status}

COVID-19 presentation symptoms were assessed, they were divided into two categories. Typical symptoms, which were, fever, cough, fatigue and headache. Atypical symptoms, which were, gastrointestinal symptoms, reduced level of consciousness and neurological presentation. $81 \%(86 / 105)$ of the patients were presented with typical symptoms, while, $2.9 \%(3 / 105)$ of patients had atypical symptoms. In the other hand, $15.2 \%(16 / 105)$ of the patients had both typical and atypical symptoms. All (3/3) of the patients who had atypical COVID-19 presentation were deceased. Of the patients who had both typical and atypical symptoms, $31.3 \%$ (5/16) were deceased. Of the patients with regular symptoms, $25.6 \%$ (22/86) were deceased. A statistically significant association ( likelihood ratio= 7.957, $\mathrm{p}=0.019$ ) was found between COVID-19 presentation and mortality.

Association between the duration of hospitalization and complications was assessed with regards to mortality, but no statistically significant association was found ( $p>0.05)$, table 2. 
medRxiv preprint doi: https://doi.org/10.1101/2021.03.09.21253179; this version posted March 11, 2021. The copyright holder for this preprint (which was not certified by peer review) is the author/funder, who has granted medRxiv a license to display the preprint in perpetuity.

It is made available under a CC-BY-NC-ND 4.0 International license .

Enoxaparin doses used in the treatment of COVID-19 patients were evaluated. 14.3\% $(15 / 105)$ of the patients received therapeutic doses, $26.7 \%(4 / 11)$ of them were deceased. No statistically significant difference was found between mortality rate and enoxaparin therapeutic dose $(p=0.859) .60 \%(63 / 105)$ of the patients received high prophylactic doses, $40 \mathrm{mg}$ twice daily. Of those, $17.5 \%$ (11/63) were deceased, while $45.2 \%$ of the patients who did not receive high prophylactic doses of enoxaparin were deceased. A statistically significant difference was found between mortality rate and enoxaparin high prophylactic doses $(p=0.002)$. Patients who received standard prophylactic enoxaparin doses were $18.1 \%$ (19/105), of those patients $57.9 \%$ (11/19) were deceased, while, $22.1 \%$ of these patients who did not receive prophylactic enoxaparin doses were deceased $(p=0.002)$. In the other hand, $50 \%$ of patients who did not receive any anticoagulant were deceased $(p=0.183)$. Table 2 below, illustrates the association between COVID-19 presentation and treatment with regards to mortality.

Table 2: Presentation and treatment of COVID-19 patients based on the mortality status $(\mathbf{n}=\mathbf{1 0 5})$

\begin{tabular}{|c|c|c|c|c|c|c|c|c|}
\hline \multirow[b]{2}{*}{ Variables } & \multicolumn{4}{|c|}{ Mortality } & \multirow[b]{2}{*}{ Total } & \multirow[b]{2}{*}{$\%$} & \multirow[b]{2}{*}{$\begin{array}{l}\text { Likelihood } \\
\text { ratio }\end{array}$} & \multirow[b]{2}{*}{$p$-value } \\
\hline & Deceased & $\%$ & Alive & $\%$ & & & & \\
\hline Presentation & & & & & & & 7.957 & 0.019 \\
\hline Typical symptoms & 22 & 25.6 & 64 & 74.4 & 86 & 81.9 & & \\
\hline Atypical symptoms & 3 & 100.0 & 0 & 0.0 & 3 & 2.9 & & \\
\hline Both & 5 & 31.3 & 11 & 68.8 & 16 & 15.2 & & \\
\hline Total & 30 & 28.6 & 75 & 71.4 & 105 & 100.0 & & \\
\hline Duration of hospitalization & & & & & & & $0.071^{*}$ & 0.79 \\
\hline$<=5$ days & 20 & 27.8 & 52 & 72.2 & 72 & 68.6 & & \\
\hline$>5$ days & 10 & 30.3 & 23 & 69.7 & 33 & 31.4 & & \\
\hline Total & 30 & 28.6 & 75 & 71.4 & 105 & 100.0 & & \\
\hline Complications & & & & & & & 3.01 & 0.222 \\
\hline Stroke & 1 & 20.0 & 4 & 80.0 & 5 & 4.8 & & \\
\hline AKI & 0 & 0.0 & 4 & 100.0 & 4 & 3.8 & & \\
\hline None & 29 & 30.2 & 67 & 69.8 & 96 & 91.4 & & \\
\hline Total & 30 & 28.6 & 75 & 71.4 & 105 & 100.0 & & \\
\hline Enoxaparin dose & & & & & & & & \\
\hline Therapeutic & & & & & & & 0.031 & 0.859 \\
\hline Yes & 4 & 26.7 & 11 & 73.3 & 15 & 14.3 & & \\
\hline No & 26 & 28.9 & 64 & 71.1 & 90 & 85.7 & & \\
\hline Total & 30 & 28.6 & 75 & 71.4 & 105 & 100.0 & & \\
\hline High prophylactic & & & & & & & $9.528 *$ & 0.002 \\
\hline Yes & 11 & 17.5 & 52 & 82.5 & 63 & 60.0 & & \\
\hline No & 19 & 45.2 & 23 & 54.8 & 42 & 40.0 & & \\
\hline Total & 30 & 28.6 & 75 & 71.4 & 105 & 100.0 & & \\
\hline
\end{tabular}


medRxiv preprint doi: https://doi.org/10.1101/2021.03.09.21253179; this version posted March 11, 2021. The copyright holder for this preprint (which was not certified by peer review) is the author/funder, who has granted medRxiv a license to display the preprint in perpetuity.

It is made available under a CC-BY-NC-ND 4.0 International license .

\begin{tabular}{lllllllll}
\hline Prophylactic & & & & & & & $9.774^{*}$ & 0.002 \\
Yes & 11 & 57.9 & 8 & 42.1 & 19 & 18.1 & & \\
No & 19 & 22.1 & 67 & 77.9 & 86 & 81.9 & & \\
Total & 30 & 28.6 & 75 & 71.4 & 105 & 100.0 & & \\
No prophylaxis & & & & & & & 1.714 & 0.183 \\
Yes & 4 & 50.0 & 4 & 50.0 & 8 & 7.6 & & \\
No & 26 & 26.8 & 71 & 73.2 & 97 & 92.4 & & \\
Total & 30 & 28.6 & 75 & 71.4 & 105 & 100.0 & \\
\hline
\end{tabular}

${ }^{*}$ Chi-square test

\section{Odds ratio of the associated variables to COVID-19 mortality}

All the variables associated with COVID-19 mortality were assessed, their odds ratios were described in table 3 below. Age, gender and comorbidities were assessed besides the admission and duration of hospitalization. As well as, the symptoms and complications of COVID-19 infection (table 3). Forest plot for the odds ratios of all the variables and their $95 \%$ confidence intervals was presented below (figure 2).

Table 3: Odds ratio of the associated variables to COVID-19 mortality

\begin{tabular}{|c|c|c|c|c|c|c|}
\hline \multirow[b]{2}{*}{ Variables } & \multicolumn{4}{|c|}{ Mortality } & \multirow[b]{2}{*}{ Total } & \multirow[b]{2}{*}{ Odds Ratio $(95 \% \mathrm{Cl})$} \\
\hline & Deceased & $\%$ & Alive & $\%$ & & \\
\hline \multicolumn{6}{|l|}{ Age: } & $0.268(0.074-0.975)$ \\
\hline$\leq 60$ years & 3 & 12.0 & 22 & 88.0 & 25.0 & \\
\hline$>60$ years & 27 & 33.8 & 53 & 66.3 & 80.0 & \\
\hline \multicolumn{5}{|l|}{ Gender: } & & $1.261(0.518-3.071)$ \\
\hline Male & 20 & 30.3 & 46 & 69.7 & 66.0 & \\
\hline Female & 10 & 25.6 & 29 & 74.4 & 39.0 & \\
\hline \multicolumn{5}{|l|}{ Admission: } & & $0.308(0.112-0.845)$ \\
\hline Isolation ward & 20 & 23.5 & 65 & 76.5 & 85.0 & \\
\hline Isolation ICU & 10 & 50.0 & 10 & 50.0 & 20.0 & \\
\hline \multicolumn{6}{|c|}{ Duration of hospitalization: } & $0.885(0.358-2.184)$ \\
\hline$<=5$ days & 20 & 27.8 & 52 & 72.2 & 72.0 & \\
\hline$>5$ days & 10 & 30.3 & 23 & 69.7 & 33.0 & \\
\hline \multicolumn{7}{|l|}{ Comorbidities: } \\
\hline \multicolumn{6}{|l|}{$D M$} & $1.455(0.622-3.403)$ \\
\hline Yes & 16 & 32.7 & 33 & 67.3 & 49.0 & \\
\hline No & 14 & 25.0 & 42 & 75.0 & 56.0 & \\
\hline \multicolumn{6}{|l|}{ HTN } & $2.129(0.898-5.046)$ \\
\hline Yes & 18 & 36.7 & 31 & 63.3 & 49.0 & \\
\hline No & 12 & 21.4 & 44 & 78.6 & 56.0 & \\
\hline \multicolumn{5}{|l|}{$D M+H T N$} & & $2.275(0.917-5.643)$ \\
\hline Yes & 12 & 41.4 & 17 & 58.6 & 29.0 & \\
\hline No & 18 & 23.7 & 58 & 76.3 & 76.0 & \\
\hline \multicolumn{5}{|l|}{$I H D$} & & $0.828(0.083-8.286)$ \\
\hline Yes & 1 & 25.0 & 3 & 75.0 & 4.0 & \\
\hline No & 29 & 28.7 & 72 & 71.3 & 101.0 & \\
\hline \multicolumn{5}{|l|}{ Complications: } & & $1.423(1.253-1.615)$ \\
\hline \multicolumn{7}{|l|}{$A K I$} \\
\hline Yes & 0 & 0.0 & 4 & 100.0 & 4.0 & \\
\hline No & 30 & 29.7 & 71 & 70.3 & 101.0 & \\
\hline
\end{tabular}


medRxiv preprint doi: https://doi.org/10.1101/2021.03.09.21253179; this version posted March 11, 2021. The copyright holder for this preprint (which was not certified by peer review) is the author/funder, who has granted medRxiv a license to display the preprint in perpetuity. It is made available under a CC-BY-NC-ND 4.0 International license.

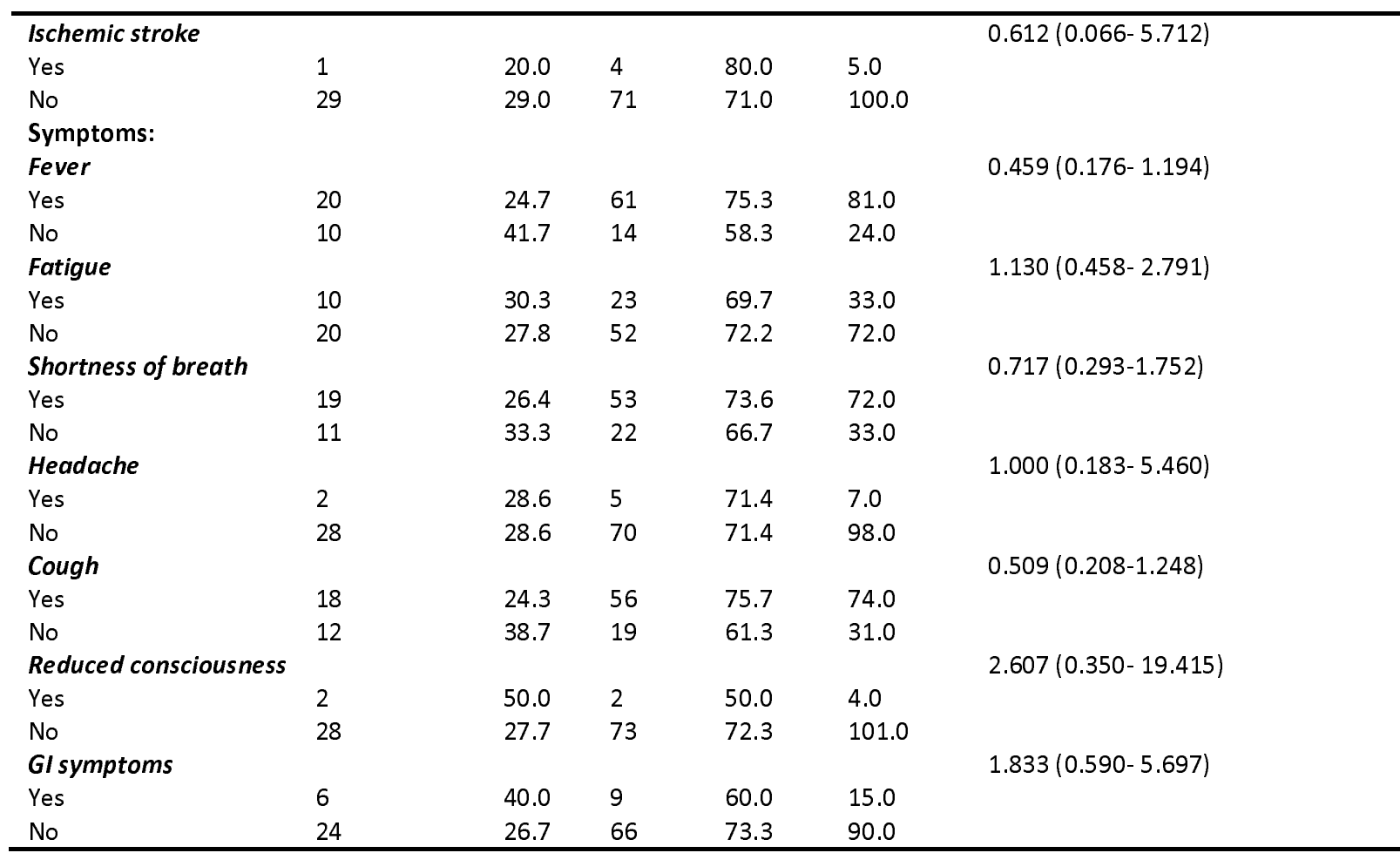




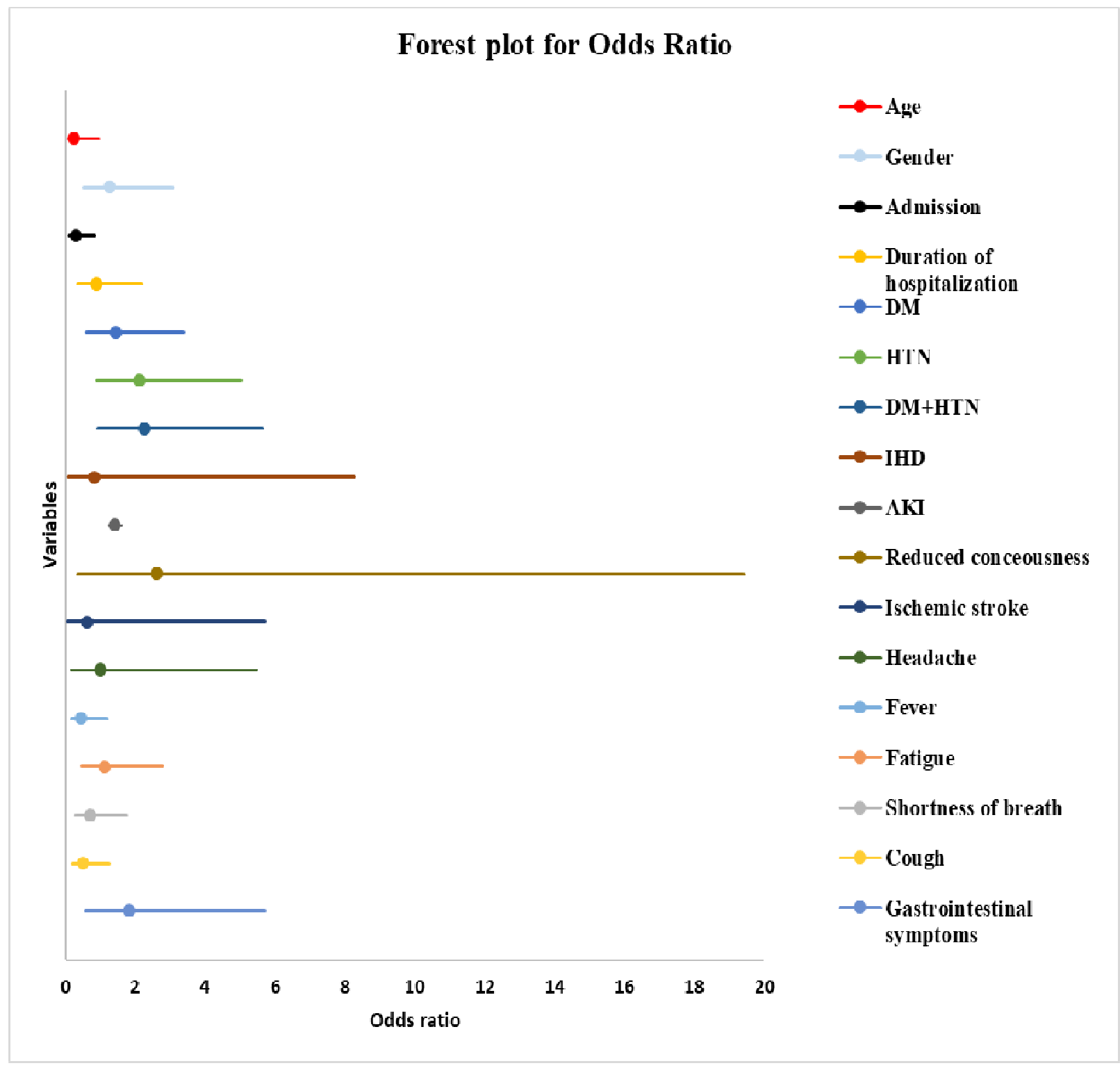

Figure 2: Forest plot for odds ratio of variables associated to COVID-19 mortality

\section{Logistic regression model for predicting the mortality among COVID-19 patients}

Our equation for the regression model fitted the model perfectly $\left(\mathrm{Chi}^{2}=28.030, p=\right.$ 0.001 ), the model equation was as follows: 
medRxiv preprint doi: https://doi.org/10.1101/2021.03.09.21253179; this version posted March 11, 2021. The copyright holder for this preprint (which was not certified by peer review) is the author/funder, who has granted medRxiv a license to display the preprint in perpetuity.

It is made available under a CC-BY-NC-ND 4.0 International license .

Mortality $=-14.724+(1.387 *$ Age $)+(-0.323 *$ Gender $)+(1.814 *$ Admission $)+(0.193 *$

Ischemic Heart Disease $)+(-0.369 *$ Fever $)+(1.595 *$ Cough $)+(1.953 *$ Complications $)$

$+(0.149 *$ Duration of hospitalization $)+(0.999 *$ Enoxaparin dose $)$.

Age, admission ward, cough and enoxaparin dose were statistically significant predictors for COVID-19 mortality ( $p=0.014,0.011,0.015,0.006$ respectively). In the other hand, gender and fever had negative influence to mortality. Although, complications was not a statistically significant factor $(p=0.100)$, it contributed by more than seven times in our model ( OR=7.051, CI: 0.69- 72.046). Table 4 below illustrates the predicting factors of the logistic regression model for COVID-19 mortality.

Table 4: Mortality prediction model for COVID-19 patients

\begin{tabular}{|c|c|c|c|c|c|c|c|c|}
\hline \multirow[b]{2}{*}{ Factors } & \multirow[b]{2}{*}{ B } & \multirow[b]{2}{*}{ S.E. } & \multirow[b]{2}{*}{ Wald } & \multirow[b]{2}{*}{ df } & \multirow[b]{2}{*}{$p$-value } & \multirow[b]{2}{*}{ OR } & \multicolumn{2}{|c|}{$95 \%$ CI for OR } \\
\hline & & & & & & & Lower & Upper \\
\hline Intercept & -14.724 & 4.498 & 10.714 & 1 & 0.001 & & & \\
\hline Age & 1.387 & 0.562 & 6.087 & 1 & $0.014 *$ & 4.005 & 1.33 & 12.057 \\
\hline Gender & -0.323 & 0.544 & 0.354 & 1 & 0.552 & 0.724 & 0.249 & 2.101 \\
\hline Admission & 1.814 & 0.715 & 6.441 & 1 & $0.011 *$ & 6.134 & 1.511 & 24.892 \\
\hline IHD** & 0.193 & 1.374 & 0.02 & 1 & 0.888 & 1.213 & 0.082 & 17.912 \\
\hline Fever & -0.369 & 0.729 & 0.256 & 1 & 0.613 & 0.692 & 0.166 & 2.888 \\
\hline Cough & 1.595 & 0.659 & 5.861 & 1 & $0.015^{*}$ & 4.93 & 1.355 & 17.936 \\
\hline Complications & 1.953 & 1.186 & 2.713 & 1 & 0.100 & 7.051 & 0.69 & 72.046 \\
\hline $\begin{array}{l}\text { Duration of } \\
\text { hospitalization }\end{array}$ & 0.149 & 0.393 & 0.144 & 1 & 0.705 & 1.161 & 0.537 & 2.507 \\
\hline Enoxaparin dose & 0.999 & 0.36 & 7.691 & 1 & $0.006^{*}$ & 2.716 & 1.34 & 5.502 \\
\hline
\end{tabular}

*Statistically significant, **Ischemic Heart Disease

\section{Discussion}

Mortality rate among Sudanese patients with COVID-19 infection was (29\%), this was higher than reported rates $(17.6 \%$ and $3.9 \%)$ in published studies $[8,12]$. However, this rate was lower than the rate reported in Brazil [19].

Age was significantly associated with mortality $(p=0.034)$, consistent with $[1,20]$. None of the participants who aged $\leq 45$ years had died, consistently with a developed mortality score [16] in which, patients aged below 50 years had no points in the score. While, $33.3 \%$ of patients above 60 years were deceased $(\mathrm{p}=0.034)$. Our results were comparable to the reported mortality rates $(11.7 \%$ and $54.2 \%)$ for age groups between $65-69$ years 
medRxiv preprint doi: https://doi.org/10.1101/2021.03.09.21253179; this version posted March 11, 2021. The copyright holder for this preprint

and above 80 years, respectively [6]. In a Spanish study [4] assessing the association between age and mortality, 95.3\% of deceased COVID-19 patients aged 60 years and above, $(p=0.006)$.

Gender had no statistically significant association with mortality, this was in contrast with published studies [1, 16, 20] and in line with an English and a Brazilian studies, in which, mortality rates were the same among males and females [19, 21].

In our study, mortality among severe cases (19\%) was higher than the rates reported in a Japanese study (12\%) and in a Vietnamese study (16\%) among severe cases [22, 23]. $19 \%$ of our patients were admitted to the isolation ICU, this percent was higher than the percent reported (12\%) in a cohort study [12] and similar to another study [13], in which, critical cases were $(19.5 \%)$ of patients. Patients who were admitted to the ICU had higher mortality rate $(50 \%)$ than patients who were admitted to the general ward $(23.5 \%)$.

The reported comorbidities were, DM, HTN, DM+HTN, and IHD. These were similar to reported comorbidities [8, 24] besides other comorbidities. In our study, (33\%) of the diabetic patients were deceased, while, in Brazil, the rates were higher [19]. The odds ratio for diabetes as a related factor to mortality among our patients was 1.455 (95\% $\mathrm{CI}=0.622-3.403, \mathrm{p}=0.386)$, while in another study [2], it was 0.099 (95\% CI=0.0160.627, $p=0.014)$. Interestingly, when we assessed the association between comorbidities of the patients and COVID-19 mortality, no statistically significant association was found between these comorbidities and mortality $(p>0.05)$. Consistent with the results reported $[1,4,12]$. Contrary to a study reported that DM and HTN had a statistically significant association with mortality [20]. In our study, the percent of COVID-19 patients with hypertension who were deceased was $37 \%$, this was comparable to the percentages reported in a systematic review [11], in which, COVID-19 mortality rate in patients with HTN ranged between ( $30.5 \%)$ and $(64.7 \%)$.

Symptoms of COVID-19 presentation were assessed in our patients. The patients who presented with atypical symptoms, as gastro-intestinal (GI) symptoms and reduced consciousness, had the highest mortality rate (100\%). GI symptoms had an odds ratio of 1.833 (95\% CI=0.590-5.697). While, in a published study [25], the odds ratios for nausea 
medRxiv preprint doi: https://doi.org/10.1101/2021.03.09.21253179; this version posted March 11, 2021. The copyright holder for this preprint

and vomiting were $(0.63$ [ $0.38-1.04]$ and 0.92 [0.59-1.44] respectively). Patients who were presented with typical symptoms had (25.6\%) mortality rate.

The duration of hospitalization had no statistically significant association with mortality. As well as, the complications, as stroke and acute kidney injury (AKI), caused by COVID-19 infection had no statistically significant association to mortality. As in a study, (15\%) of patients who died from COVID-19 infection had no complications [4].

Standard thrombo-prophylaxis is not enough for COVID-19 patients [26]. Patients in our study, who had no anticoagulation treatment had (50\%) mortality rate $(p=0.183)$, while patients who received high prophylactic doses of enoxaparin, $40 \mathrm{mg}$ twice daily, had the lowest mortality rate $(17.5 \% ; p=0.002)$. What interesting is, the mortality rate of patients who received therapeutic enoxaparin doses was higher than in patients who received high prophylactic doses. This was consistent with the results of a published study in the United States [27], in which, prophylactic enoxaparin dose had statistically significant difference in mortality ( $p=0.001$ ), while therapeutic dose had no statistically significant difference $(p=0.57)$. Clinical trials are still being conducted to compare the efficacy between prophylactic and therapeutic doses of enoxaparin among COVID-19 patients [28, 29].

The prediction of mortality among our patients was performed through logistic regression. Our model had perfect fit $(p=0.001)$. Age was a statistically significant factor, consistent with published literature [7, 12, 24, 30]. Admission, cough and enoxaparin dose were statistically significant prediction factors $(p<0.05)$. Interestingly, gender was not a significant predictor of mortality in our study patients, this was contrary to the results of published prediction models [7, 12]. Although, complications was not statistically significant ( $p=0.100$ ), it contributed by more than seven times in our model ( $\mathrm{OR}=7.051$, CI: 0.69- 72.046). Fever was not statistically significant, in line with a published model [12] and in contrast with [7]. In our model, IHD was not a statistically significant predictor contrary to a published study [24].

The limitations of our study were the size of the study, as it was a single centre study. The data collection sheet was not standardized, only validated through an expert in 
research methods. Besides the retrospective nature of data collection which might affect the quality of the data collection.

\section{Conclusions}

Age, admission, cough and enoxaparin dose were statistically significant prediction factors $(p<0.05)$ for mortality rate among hospitalized COVID-19 patients. Interestingly, gender was not a significant predictor of mortality in our study patients, alongside with comorbidities.

\section{Recommendations}

Special care must be provided for patients older than 60 years and intensifying the preventive measures for this slide of the community as they are the vulnerable population group. Multi-centre wider studies to confirm these results will be of high significance. Also, assessment of enoxaparin prophylactic and therapeutic doses in a direct causeeffect study must be conducted to define the most suitable dose for hospitalized COVID19 patients.

\section{Abbreviations}

AKI: Acute Kidney Injury

DM: Diabetes Mellitus

GI: Gastro-Intestinal

HTN: Hypertension

ICU: Intensive Care Unit

MOH: Ministry Of Health

IHD: Ischemic Heart Disease

IRB: Institutional Review Board

OCHA: Office for the Coordination of Humanitarian Affairs

\section{Declarations}




\section{Ethics Approval and Consent to Participate}

Ethical approval was obtained from the Medical administration of Imperial Hospital. The study proposal was submitted to the research administration at the State Ministry Of Health $(\mathrm{MOH})$, Khartoum. Expedited review was conducted by the IRB of the $\mathrm{MOH}$ and approval was granted. Another copy of the proposal was submitted to the Administration of Private Medical Facilities. Regarding participants, the data were collected retrospectively from medical records and their confidentiality was assured with the use of an anonymous research tool. Informed consents from the patients/ surrogate decision makers were obtained by contacting them through their registered phone numbers. The collected data were used strictly for the purpose of the study objectives.

\section{Consent for publication}

All authors have read the final manuscript and gave their consent for the article to be published in Infection. No clinical details of participants that might compromise their anonymity were used in the development of this manuscript titled "Prediction of COVID-19 mortality among hospitalized patients in Sudan”.

\section{Availability of supporting data}

All supporting data are available.

\section{Competing interests}

The authors declared no competing interest.

\section{Funding}

No funding was applied for this study. 
medRxiv preprint doi: https://doi.org/10.1101/2021.03.09.21253179; this version posted March 11, 2021. The copyright holder for this preprint (which was not certified by peer review) is the author/funder, who has granted medRxiv a license to display the preprint in perpetuity.

It is made available under a CC-BY-NC-ND 4.0 International license .

\section{Authors' contributions}

All authors have read the final manuscript and gave their approval for publication.

GOHA: Wrote the manuscript, conducted the analysis and assisted in the data collection.

MAAY: Collected the data, assisted in getting the ethical approval, read the first draft of the manuscript and proof read the final manuscript prior to submission.

DSIM: Facilitated the administrative arrangements at Imperial Hospital, assisted in the data collection and read the final manuscript prior to submission.

\section{Acknowledgments}

The authors are grateful to Shurouq O. H. Abdelraheem, Faculty of Engineering, University of Khartoum for her assistance in the data entry process. The authors also acknowledge the cooperation of the departments of Imperial Hospital during the data collection.

\section{References}

1. Hu C, Liu Z, Jiang Y, Shi O, Zhang X, Xu K, Suo C, Wang Q, Song Y, Yu K, Mao X, Wu X, Wu M, Shi T, Jiang W, Mu L, Tully DC, Xu L, Jin L, Li S, Tao X, Zhang T, Chen $\mathrm{X}$. Early prediction of mortality risk among patients with severe COVID-19, using machine learning. Int J Epidemiol. 2020 Sep 23:dyaa171. doi: 10.1093/ije/dyaa171. Epub ahead of print. PMID: 32997743; PMCID: PMC7543461.

2. Liu SP, Zhang Q, Wang W, Zhang M, Liu C, Xiao X, Liu Z, Hu WM, Jin P. Hyperglycemia is a strong predictor of poor prognosis in COVID-19. Diabetes Res Clin Pract. 2020 Sep;167:108338. doi: 10.1016/j.diabres.2020.108338. Epub 2020 Jul 24. PMID: 32712122; PMCID: PMC7377976.

3. Shao A, Zhou Y, Tu S, Sheng J. A novel scoring system in mortality prediction of severe patients with COVID-19. EClinicalMedicine. 2020 Jul 15;24:100450. doi: 10.1016/j.eclinm.2020.100450. PMID: 32691020; PMCID: PMC7361103. 
4. Cobos-Siles M, Cubero-Morais P, Arroyo-Jiménez I, Rey-Hernández M, HernándezGómez L, Vargas-Parra DJ, González-Fernández M, Cazorla-González M, GabellaMartín M, Ruíz-Albi T, Berezo-García JA, García-Cruces-Méndez JF, MiramontesGonzález JP, Corral-Gudino L. Cause-specific death in hospitalized individuals infected with SARS-CoV-2: more than just acute respiratory failure or thromboembolic events. Intern Emerg Med. 2020 Nov;15(8):1533-1544. doi: 10.1007/s11739-020-02485-y. Epub 2020 Sep 10. PMID: 32910363; PMCID: PMC7481346.

5. Veiga E Silva L, de Andrade Abi Harb MDP, Teixeira Barbosa Dos Santos AM, de Mattos Teixeira CA, Macedo Gomes VH, Silva Cardoso EH, S da Silva M, Vijaykumar NL, Venâncio Carvalho S, Ponce de Leon Ferreira de Carvalho A, Lisboa Frances CR. COVID-19 Mortality Underreporting in Brazil: Analysis of Data From Government Internet Portals. J Med Internet Res. 2020 Aug 18;22(8):e21413. doi: 10.2196/21413. PMID: 32730219; PMCID: PMC7446715.

6. Becerra-Muñoz VM, Núñez-Gil IJ, Eid CM, Aguado MG, Romero R, Huang J, Mulet A, Ugo F, Rametta F, Liebetrau C, Aparisi A, Fernández-Rozas I, Viana-Llamas MC, Feltes G, Pepe M, Moreno-Rondón LA, Cerrato E, Raposeiras-Roubín S, Alfonso E, CarreroFernández A, Buzón-Martín L, Abumayyaleh M, Gonzalez A, Ortiz AF, Macaya C, Estrada V, Fernández-Pérez C, Gómez-Doblas JJ. Clinical profile and predictors of inhospital mortality among older patients admitted for COVID-19. Age Ageing. 2020 Nov 17:afaa258. doi: 10.1093/ageing/afaa258. Epub ahead of print. PMID: 33201181; PMCID: PMC7717146.

7. Altschul DJ, Unda SR, Benton J, de la Garza Ramos R, Cezayirli P, Mehler M, Eskandar EN. A novel severity score to predict inpatient mortality in COVID-19 patients. Sci Rep. 2020 Oct 7;10(1):16726. doi: 10.1038/s41598-020-73962-9. PMID: 33028914; PMCID: PMC7542454.

8. Bao C, Tao X, Cui W, Yi B, Pan T, Young KH, Qian W. SARS-CoV-2 induced thrombocytopenia as an important biomarker significantly correlated with abnormal coagulation function, increased intravascular blood clot risk and mortality in COVID-19 patients. Exp Hematol Oncol. 2020 Jul 17;9:16. doi: 10.1186/s40164-020-00172-4. PMID: 32695551; PMCID: PMC7366559.

9. Meo SA, Abukhalaf AA, Alomar AA, Aljudi TW, Bajri HM, Sami W, Akram J, Akram SJ, Hajjar W. Impact of weather conditions on incidence and mortality of COVID-19 pandemic in Africa. Eur Rev Med Pharmacol Sci. 2020 Sep;24(18):9753-9759. doi: 10.26355/eurrev_202009_23069. PMID: 33015822.

10. Frontera A, Cianfanelli L, Vlachos K, Landoni G, Cremona G. Severe air pollution links to higher mortality in COVID-19 patients: The "double-hit" hypothesis. J Infect. 2020 Aug;81(2):255-259. doi: 10.1016/j.jinf.2020.05.031. Epub 2020 May 21. PMID: 32447007; PMCID: PMC7240268. 
medRxiv preprint doi: https://doi.org/10.1101/2021.03.09.21253179; this version posted March 11, 2021. The copyright holder for this preprint (which was not certified by peer review) is the author/funder, who has granted medRxiv a license to display the preprint in perpetuity.

It is made available under a CC-BY-NC-ND 4.0 International license .

11. Li X, Guan B, Su T, Liu W, Chen M, Bin Waleed K, Guan X, Gary T, Zhu Z. Impact of cardiovascular disease and cardiac injury on in-hospital mortality in patients with COVID-19: a systematic review and meta-analysis. Heart. 2020 Aug;106(15):1142-1147. doi: 10.1136/heartjnl-2020-317062. Epub 2020 May 27. PMID: 32461330; PMCID: PMC7295861.

12. Zhang S, Guo M, Duan L, Wu F, Hu G, Wang Z, Huang Q, Liao T, Xu J, Ma Y, Lv Z, Xiao W, Zhao Z, Tan X, Meng D, Zhang S, Zhou E, Yin Z, Geng W, Wang X, Zhang J, Chen J, Zhang Y, Jin Y. Development and validation of a risk factor-based system to predict short-term survival in adult hospitalized patients with COVID-19: a multicenter, retrospective, cohort study. Crit Care. 2020 Jul 16;24(1):438. doi: 10.1186/s13054-02003123-x. PMID: 32678040; PMCID: PMC7364297.

13. Shi S, Liu X, Xiao J, Wang H, Chen L, Li J, Han K. Prediction of adverse clinical outcomes in patients with coronavirus disease 2019. J Clin Lab Anal. 2020 Sep 28:e23598. doi: 10.1002/jcla.23598. Epub ahead of print. PMID: 32989838; PMCID: PMC7536920.

14. Blangiardo M, Cameletti M, Pirani M, Corsetti G, Battaglini M, Baio G. Estimating weekly excess mortality at sub-national level in Italy during the COVID-19 pandemic. PLoS One. 2020 Oct 9;15(10):e0240286. doi: 10.1371/journal.pone.0240286. PMID: 33035253; PMCID: PMC7546500.

15. Soubeyrand S, Ribaud M, Baudrot V, Allard D, Pommeret D, Roques L. COVID-19 mortality dynamics: The future modelled as a (mixture of) past(s). PLoS One. $2020 \mathrm{Sep}$ 11;15(9):e0238410. doi: 10.1371/journal.pone.0238410. PMID: 32915815; PMCID: PMC7485826.

16. Knight SR, Ho A, Pius R, Buchan I, Carson G, Drake TM, Dunning J, Fairfield CJ, Gamble C, Green CA, Gupta R, Halpin S, Hardwick HE, Holden KA, Horby PW, Jackson C, Mclean KA, Merson L, Nguyen-Van-Tam JS, Norman L, Noursadeghi M, Olliaro PL, Pritchard MG, Russell CD, Shaw CA, Sheikh A, Solomon T, Sudlow C, Swann OV, Turtle LC, Openshaw PJ, Baillie JK, Semple MG, Docherty AB, Harrison EM; ISARIC4C investigators. Risk stratification of patients admitted to hospital with covid-19 using the ISARIC WHO Clinical Characterisation Protocol: development and validation of the 4C Mortality Score. BMJ. 2020 Sep 9;370:m3339. doi: 10.1136/bmj.m3339. Erratum in: BMJ. 2020 Nov 13;371:m4334. PMID: 32907855; PMCID: PMC7116472.

17. Wang T, Paschalidis A, Liu Q, Liu Y, Yuan Y, Paschalidis IC. Predictive Models of Mortality for Hospitalized Patients With COVID-19: Retrospective Cohort Study. JMIR Med Inform. 2020 Oct 15;8(10):e21788. doi: 10.2196/21788. PMID: 33055061; PMCID: PMC7572117.

18. OCHA Sudan situation report. https://reports.unocha.org/en/country/sudan. 19 Dec 2020 
19. Baqui P, Bica I, Marra V, Ercole A, van der Schaar M. Ethnic and regional variations in hospital mortality from COVID-19 in Brazil: a cross-sectional observational study. Lancet Glob Health. 2020 Aug;8(8):e1018-e1026. doi: 10.1016/S2214-109X(20)30285-0. Epub 2020 Jul 2. PMID: 32622400; PMCID: PMC7332269.

20. Rodilla E, Saura A, Jiménez I, Mendizábal A, Pineda-Cantero A, Lorenzo-Hernández E, Fidalgo-Montero MDP, López-Cuervo JF, Gil-Sánchez R, Rabadán-Pejenaute E, AbellaVázquez L, Giner-Galvañ V, Solís-Marquínez MN, Boixeda R, Peña-Fernández A, Carrasco-Sánchez FJ, González-Moraleja J, Torres-Peña JD, Guisado-Espartero ME, Escobar-Sevilla J, Guzmán-García M, Martín-Escalante MD, Martínez-González ÁL, Casas-Rojo JM, Gómez-Huelgas R. Association of Hypertension with All-Cause Mortality among Hospitalized Patients with COVID-19. J Clin Med. 2020 Sep 28;9(10):3136. doi: 10.3390/jcm9103136. PMID: 32998337; PMCID: PMC7650567.

21. de Lusignan S, Joy M, Oke J, McGagh D, Nicholson B, Sheppard J, Akinyemi O, Amirthalingam G, Brown K, Byford R, Dabrera G, Krajenbrink E, Liyanage H, LopezBernal J, Okusi C, Ramsay M, Sherlock J, Sinnathamby M, Tsang RSM, Tzortziou Brown V, Williams J, Zambon M, Ferreira F, Howsam G, Hobbs FDR. Disparities in the excess risk of mortality in the first wave of COVID-19: Cross sectional study of the English sentinel network. J Infect. 2020 Nov;81(5):785-792. doi: 10.1016/j.jinf.2020.08.037. Epub 2020 Aug 25. PMID: 32858068; PMCID: PMC7446615.

22. Saito S, Asai Y, Matsunaga N, Hayakawa K, Terada M, Ohtsu H, Tsuzuki S, Ohmagari N. First and second COVID-19 waves in Japan: A comparison of disease severity and characteristics. J Infect. 2020 Nov 2:S0163-4453(20)30693-9. doi: 10.1016/j.jinf.2020.10.033. Epub ahead of print. PMID: 33152376; PMCID: PMC7605825.

23. Thai PQ, Toan DTT, Son DT, Van HTH, Minh LN, Hung LX, Toan NV, Hoat LN, Luong DH, Khue LN, Khoa NT, Huong LT. Factors associated with the duration of hospitalisation among COVID-19 patients in Vietnam: A survival analysis. Epidemiol Infect. 2020 Jun 10;148:e114. doi: 10.1017/S0950268820001259. PMID: 32517822; PMCID: PMC7306545.

24. Fernández-Cruz A, Ruiz-Antorán B, Muñoz-Gómez A, Sancho-López A, Mills-Sánchez P, Centeno-Soto GA, Blanco-Alonso S, Javaloyes-Garachana L, Galán-Gómez A, Valencia-Alijo Á, Gómez-Irusta J, Payares-Herrera C, Morrás-Torre I, Sánchez-Chica E, Delgado-Téllez-de-Cepeda L, Callejas-Díaz A, Ramos-Martínez A, Múñez-Rubio E, Avendaño-Solá C. A Retrospective Controlled Cohort Study of the Impact of Glucocorticoid Treatment in SARS-CoV-2 Infection Mortality. Antimicrob Agents Chemother. 2020 Aug 20;64(9):e01168-20. doi: 10.1128/AAC.01168-20. PMID: 32571831; PMCID: PMC7449182.

25. Zhang Y, Ma P, Zhang X, Pei Z, Wang H, Dou X. Association of digestive symptoms with severity and mortality of COVID-19: A protocol for systematic review and meta- 
medRxiv preprint doi: https://doi.org/10.1101/2021.03.09.21253179; this version posted March 11, 2021. The copyright holder for this preprint (which was not certified by peer review) is the author/funder, who has granted medRxiv a license to display the preprint in perpetuity.

It is made available under a CC-BY-NC-ND 4.0 International license .

analysis. Medicine (Baltimore). 2020 Oct 23;99(43):e22736. doi: 10.1097/MD.0000000000022736. PMID: 33120773; PMCID: PMC7581056.

26. Artifoni M, Danic G, Gautier G, Gicquel P, Boutoille D, Raffi F, Néel A, Lecomte R. Systematic assessment of venous thromboembolism in COVID-19 patients receiving thromboprophylaxis: incidence and role of D-dimer as predictive factors. J Thromb Thrombolysis. 2020 Jul;50(1):211-216. doi: 10.1007/s11239-020-02146-z. PMID: 32451823; PMCID: PMC7246965.

27. Billett HH, Reyes-Gil M, Szymanski J, Ikemura K, Stahl LR, Lo Y, Rahman S, Gonzalez-Lugo JD, Kushnir M, Barouqa M, Golestaneh L, Bellin E. Anticoagulation in COVID-19: Effect of Enoxaparin, Heparin, and Apixaban on Mortality. Thromb Haemost. 2020 Dec;120(12):1691-1699. doi: 10.1055/s-0040-1720978. Epub 2020 Nov 13. PMID: 33186991.

28. Marietta M, Vandelli P, Mighali P, Vicini R, Coluccio V, D'Amico R; COVID-19 HD Study Group. Randomised controlled trial comparing efficacy and safety of high versus low Low-Molecular Weight Heparin dosages in hospitalized patients with severe COVID-19 pneumonia and coagulopathy not requiring invasive mechanical ventilation (COVID-19 HD): a structured summary of a study protocol. Trials. 2020 Jun 26;21(1):574. doi: 10.1186/s13063-020-04475-z. PMID: 32586394; PMCID: PMC7316577.

29. Cattaneo M, Morici N. Is thromboprophylaxis with high-dose enoxaparin really necessary for COVID-19 patients? A new "prudent" randomised clinical trial. Blood Transfus. 2020 May;18(3):237-238. doi: 10.2450/2020.0109-20. PMID: 32453692; PMCID: PMC7250693.

30. Ho FK, Petermann-Rocha F, Gray SR, Jani BD, Katikireddi SV, Niedzwiedz CL, Foster H, Hastie CE, Mackay DF, Gill JMR, O'Donnell C, Welsh P, Mair F, Sattar N, CelisMorales CA, Pell JP. Is older age associated with COVID-19 mortality in the absence of other risk factors? General population cohort study of 470,034 participants. PLoS One. 2020 Nov 5;15(11):e0241824. doi: 10.1371/journal.pone.0241824. PMID: 33152008; PMCID: PMC7644030. 
medRxiv preprint doi: https://doi.org/10.1101/2021.03.09.21253179; this version posted March 11, 2021. The copyright holder for this preprint (which was not certified by peer review) is the author/funder, who has granted medRxiv a license to display the preprint in perpetuity.

\author{
It is made available under a CC-BY-NC-ND 4.0 International license.
}

